\section{THE METAPHYSICS AND \\ ETHICS ACCORDING TO \\ THE BHAGAVADGITA AND \\ THE SUTTANTA PITAKA ${ }^{1}$}

\section{Samniang Leurmsai ${ }^{2}$}

\begin{abstract}
The purpose of this paper is to compare ideas of metaphysics and ethics written in the Bhagavadgitā text of Hinduism, and the Suttanta Pitaka, text of Buddhism. After examination, it is found that the Bhagavadgita recognizes the idea of God (brahman) and Self (ätman) which are mainly metaphysical concepts, whereas the Suttanta Pitaka rejects these ideas. Both texts agree ignorance and desire are causes of deluded actions which are responsible for the continued chain of existence and that all beings are born again repeatedly in different spheres of life driven by their intentional actions. To stop rebirth and to attain the highest goal of life (salvation), one should eliminate desire, hatred and delusion. However, the karma-forces of the Bhagavadgitā seem to be different from that of the Suttanta Pitaka, because they are under
\end{abstract}

${ }^{1}$ This paper is taken from some parts of the thesis entitled "A Critical and Comparative Study of the Bhagavadgitā and the Suttanta Pitaka," submitted for the degree of Doctor of Philosophy in Sanskrit at Banaras Hindu University, India, in 1997.

${ }^{2}$ Department of Oriental Languages, Faculty of Archaeology, Silpakorn University. the control of God. With regard to the idea of ethics, some practical paths written in both texts are really the same, but the standard of moral judgement in the Bhagavadgitā differs from the Suttanta Pițaka due to the belief in God.

\section{Introduction}

Hinduism and Buddhism are, undoubtedly, the two best known philosophical traditions of India and within these ancient traditions, the texts of the Bhagavadgitā and the Suttanta Pitaka are fundamental.

The Bhagavadgītā, considered the most influential work in Indian thought ${ }^{3}$, conveys lessons of philosophy, religion and ethics and has been a source of inspiration to millions of Indians for over two thousand years. In this unique text, the quintessence of the Upanisads, along with the teachings of Vedānta, Sānkhya and Yoga are synthesized into one harmonious whole. Thus, it is rightly regarded as representing not any one particular sect of Hinduism, but Hinduism as a whole. ${ }^{4}$

\footnotetext{
${ }^{3}$ S. Radhakrishnan, Indian Philosophy, Vol.1 (Delhi: Oxford University Press, 1993), p. 519 .

${ }^{4}$ S. Radhakrishnan, The Bhagavadgĩtā (Delhi: Harper Collins Publishers, 1994), p.12.
} 
Traditionally, it would be said that the Bhagavadgita is taught by the Blessed Nārāyaṇa himself to Arjuna, compiled by the ancient seer named Vyāsa, in the middle of the Mahābhārata. ${ }^{5}$ In fact, the conversation between Arjuna and Lord Krsna is supposed to have taken place just before the battle which is the main theme of the great epic. Among scholars, K.N. Upadhyaya argues that the Bhagavadgitā must be considered an original part of the Mahābhārata, because the larger epic refers to it often. ${ }^{6}$ But many scholars also believe that over time some additions may be made to the original Bhagavadgitā? Therefore, they have concluded that it must have first been completed sometime between the 5 th and 4 th century B.C. The current text of the Bhagavadgita consists of 700 verses, ${ }^{8}$ and is divided into eighteen chapters (adhyāyas). The Bhagavadgitā as found at present has been translated into Indian languages, English and many other Western languages, making it the most translated of any Asian text.

Within the basket of Buddhist scriptures (tipitaka), the Suttanta Pitaka is the Pali

${ }^{5}$ Swami Tapasyananda, Srimad Bhagavadgitata; The Scripture of Mankind (Madras: Sri Ramakrishna Math, 1994), p. xi; See also S. Radhakrishnan, The Bhagavadgittā, p. 10.

${ }^{6}$ K.N. Upadhyaya, Early Buddhism and the Bhagavadgītā (Delhi: Motilal Banarsidass, 1983), p. 6.

${ }^{7}$ M.R. Yardi, The Bhagavadgîtā As a Synthesis (Poona: The Bhandarkar Institute Press, 1991), p. 4.

${ }^{8}$ This number is confirmed by Sankkarācārya. Cf. Swami Gambhirananda, Bhagavadgita With the Commentary of Sarikarācārya (Calcutta: Advaita Ashrama, 1991), Introduction, p. xvii.
Canon which is a compilation of a great number of sermons and discourses in prose and verse, expounded by the Buddha himself or by his eminent disciples. ${ }^{9}$ These discourses were expounded to suit different occasions and the intellectual level of the audience. They cover a wide field of subjects, not only the fundamentals of the Dhamma, but also pragmatic guidelines to make the Dhamma meaningful and applicable to daily life.

The Suttanta Pitaka is divided into five collections (pañcanikāya), namely, the Digha Nikāya, Majjhima Nikāya, Samyutta Nikāya, Ariguttara Nikāya and Khuddaka Nikāya. It systematically groups the teaching of the discourses, into those concerned with precepts of morality (sìla), concentration (samādhi) and attainment of wisdom (pañกีa $){ }^{10}$

The completion of the Suttanta Pitaka, may have been achieved by the third Buddhist Council, during the reign of King Asoka, ${ }^{11}$ about 247 B.C., 236 years after the death of the Buddha. ${ }^{12}$

${ }^{9}$ Myanmar Pitaka Association, Twenty-Five Suttas from Mūlapannāāa (Delhi: Sri Sutguru Publications, 1990), Introduction, p. v.

${ }^{10}$ Myanmar Pitaka Association, Twenty-Five Suttas from Majjhimapaṇnāsa (Delhi: Sri Sutguru Publications, 1990), Introduction, p. iii.

${ }^{11}$ K.N. Upadhyaya, Early Buddhism and the Bhagavadgittā, p. 54.

${ }^{12}$ E.J. Thomas, The Life of Buddha As Legend and History (Delhi: Motilal Banarsidass Publishers, 1993), Introduction, pp. xviii-xix. 
Previously, it had been handed down orally (mukhapattha) and then recorded in books during the reign of King Vattagāmanī of Ceylon about 88-76 B.C. ${ }^{13}$ The Suttanta Pitaka which exists to this day in Ceylon, Burma and Thailand, is recorded in Pali language and has been systematically divided and handed down from generation to generation. Together with commentaries, it forms the huge collection of literary works that the Bhikkhus (monks) of the Order have to study and memorize in performing their "ganthadhura," (the duty of study). ${ }^{14}$

To date, there have been many studies of the metaphysical and ethical aspects of the texts of the Bhagavadgitā and the Suttanta Pitaka. A summary of these comparisons is given in the following paragraphs.

In this paper, I make reference to essential terminology of Sanskrit (in discussion of the Bhagavadgīta) and Pali (in discussion of the Suttanta Pitaka) languages for example: Atman (Sanskrit) and Attā (Pali), Nirvāṇa (Sanskrit) and Nibbāna (Pali).

${ }^{13}$ Ibid., p. 251.

${ }^{14}$ U Ko Lay, Guide to Tipitaka (Delhi: Sri Sutguru Publications, 1990), p. 2.

\section{Metaphysics $^{15}$}

The Buddha said that discussion of metaphysical questions, which are ethically useless and intellectually uncertain, does not take a person near to his or her goal, i.e. vimutti, the state of freedom from all suffering. Through the parable of the arrow, Buddha explains why he refrains from answering these questions. He points out that the real need of the man pierced with a poisoned arrow is to get rid of the arrow and be cured, rather than to wait for a fruitless investigation about the nature of the arrow, the man shooting it and so on. Life could be lost in this process. ${ }^{16}$ Instead of discussing metaphysical questions, therefore, the Buddha always tried to enlighten people on the more important questions of suffering, the origin of suffering, the cessation of suffering and the path leading to the cessation of suffering.

\footnotetext{
${ }^{15}$ Metaphysics is the inquiry which attempts to discover the ultimate reality underlying the universe. This inquiry has the fundamental aspects according as it concerns itself with the problem of Absolute (God), of soul, or of the cosmos (i.e. external reality). It appears to be the main questions that have engaged the attention of metaphysicians of all ages and of all countries, whether they be Indian or European. In this paper, the metaphysics with regard to the concepts of God (Brahman), the Self (ātman), the Action (karma) and Rebirth and the Salvation will be discussed.

${ }^{16}$ Majjhima Nikāya, I.429.
} 


\section{The Existence of God (Brahman)}

The Bhagavadgītā and the Suttanta Pitaka are fundamentally opposed to each other in the belief of the existence of God (brahman). In the Bhagavadgitā, Brahman manifests itself in the form of a personal God, Viṣnu-Nārāyaña, and also in the form of Lord $\mathrm{Krsna}^{17}$ who affirms that he is the origin and dissolution of the whole universe ${ }^{18}$ and speaks of himself as the abode of Brahman. ${ }^{19}$ Brahman is regarded as the ruler and preserver of the whole world. It is viewed as the immortal Self of man, dwelling in all beings, though they know it not. Besides, Brahman is said to be possessed of two natures; a higher (para $\vec{a}$ and a lower (apara $\vec{a},{ }^{20}$ answering to the conscious and the unconscious aspects of the universe. Concerning the origin of the universe, the Bhagavadgita holds the view that God or Brahman is the guiding principle behind the entire process of evolutions and dissolutions.

In the Suttanta Pitaka, the Buddha does not recognize the idea of God or Brahman. All ideas of the existence of God are rejected by the Buddha because reliance on a supernatural creator is detrimental to moral incentive and self-effort. According to the Buddha, people relying on God's mercy and help abandon their own efforts and offer vain prayers for the fulfillment of their desires. The futility of prayers are compared to calling one bank of the river

17 S. Radhakrishnan, The Bhagavadgītā, p. 26 .

${ }^{18}$ Bhagavadgìtā, VII.6; X.8.

${ }^{19}$ Bhagavadgītā, XIV.27.

${ }^{20}$ Bhagavadgītā, VII.5. to come to the opposite side. ${ }^{21}$ However, the Buddha does not seem to reject the idea of a supreme impersonal reality known as "brahman," provided it is viewed without any metaphysical or theological strings which relate it to the conditioned world of phenomena. In the Suttanta Pitaka, the Buddha only makes use of the word "brahman" as a synonym for "Nibbāna," the supreme reality and "Dhamma," the highest truth (enlightenment), not as reference to a God.

\section{Self and Non-Self}

With regard to the Self (âtman), according to the Bhagavadgitā, it is said that Self (âtman) is the principle of human life. It is what remains when everything that is not the Self is eliminated. ${ }^{22}$ It is independent of the body and on the dissolution of the body the Self is not annihilated. ${ }^{23}$ "As a person casts off worn out clothes and takes on others new, even so the Self leaves worn out bodies and enters into new ones." 24

The Self (ātman) is identical to Brahman. Brahman is the ultimate principle as realized in the universe, Atman is the same principle as realized in man. In other words, the former is the substance of the world and the latter is the substance of the individual, but the two are one. This identity of Brahman and Atman is briefly

\footnotetext{
${ }^{21}$ Digha Nikāya, I. 244.

${ }^{22}$ S. Radhakrishnan, The Principal Upanisads (New Delhi: HarperCollins Publishers, 1994), p. 73 .

${ }^{23}$ Chāndogya Upanisad, VIII.12.1.

${ }^{24}$ Bhagavadgîtā, II.22.
} 
expressed by the famous sayings: "That art thou," 25 and "I am Brahman"26 Therefore, the Upanisadic thinkers say that to know the Self is to know Brahman. ${ }^{27}$ One cannot point out what the Self is like. Positive definition of the Self is impossible. Yajnavalkya, therefore, says: "That Self is not this, not this (neti neti). It is incomprehensible for it cannot be comprehended." ${ }^{28}$ The Self has its own essence which we cannot describe. Its essential nature is said to be existence (sat), consciousness (cit) and bliss (ānanda). The Bhagavadgitā says that the one Self abides in all beings, and the yogi sees it as contained in all creatures. ${ }^{29}$ The Self is being in itself because it does not depend on objects for its existence; it is in everything in the living phenomenal world; it is complete consciousness and it is eternal.

However, within Buddhism, the notions of the Self (attâ), which is said to possess bliss and autonomy, are not acceptable. The Buddha flatly denies the existence in humans of an ego-entity which is permanent, blissful and autonomous. His arguments against the Self are based on an

25 tat tvam asi, Chāndogya Upanisad, VI.8.7.

${ }^{26}$ ahambrahma asmi, Bṛhadāranyaka Upanisad, I.4.10.

27 P. Deussen, The Philosophy of the Upanisads (Delhi: Oriental Books, 1979), p. 39; Cf. Prayoon Mererk, Selflessness in Sartre's Existentialism and Early Buddhism (Bangkok: Mahachula Buddhist University, 1988), p. 95.

${ }^{28}$ Brhadaranyaka Upanisad, IV.5.15.

${ }^{29}$ Bhagavadgìtā, VI. 29. analysis of the total human personalit which considers five aggregates (pañcakhandha), ${ }^{30}$ namely; form or corporeality ( $r u \bar{p} a)$, feeling (vedanā), perception (sañกa), mental formations (sankkhāra) and consciousness (viññāna). ${ }^{31}$ The Buddha said that there is nothing permanent and blissful in these aggragates and that it is wrong to cling to anything and to have conceit of the Self in any or all of them. As they neither singly nor collectively constitute any permanent Self, nor is there to be found such a Self apart from them, the Buddha concludes that the so-called person (puggala) is a mere collection of the five aggregates. In this matter, Buddhaghosa (the commentator who explains the Tipitaka) explains that when the five clinging aggregates exist, the mere word "being, "or "person" comes into use, but in the ultimate sense there just is name-and-form (nāma-rūpa). ${ }^{32}$ Actually, the five aggregates are non-Self because they lack permanence and bliss, which are regarded as the essential characteristics of the Self (attâ).

${ }^{30}$ The personality of man is composed of two parts, viz., name (nāma) and form (rūpa). The form (rüpa) consists of the four primary elements of earth (pathavi), water ( $\bar{a} p o$ ), fire (tejo) and wind (vāyo) while the name (nāma) is divided into four groups, viz., feeling (vedana), perception (sañna), mental formations (sankhhāra) and consciousness (viñ̃nāna). The matter or form (rūpa) and the four mental qualities are traditionally called "pañcakhandha"

${ }^{31}$ Digha Nikāya, II.307.

${ }^{32}$ Visuddhimagga, p. 593-594. 
Moreover, the theory of Anattā (non-Self), stated by the Buddha in his second sermon called "Anattalakkhana Sutta," ${ }^{33}$ clearly proclaims the impersonality of all living phenomena of existence; that there is no Self, nothing belongs to the Self. The Dhammapada also states: "All things (sabbe dhammā) are non-Self." ${ }^{34}$ This indicates that there is no Self or substance, not only in the five aggregates, but also everywhere outside them or apart from them. The word "dhamma" has a very broad meaning which includes not only conditioned things but also nonconditioned things, i.e. nibbāna. ${ }^{35}$ The theory of Anattā (non-Self) is considered one of the main corner-stones upon which the edifice of the Buddha's teachings is built. It is recorded as a specially important, elevated teaching of the Buddha. ${ }^{36}$

According to the Buddha, all phenomena are subject to the laws of causation and nothing is eternal (behind the world and individual). Every element, though appearing only for a single moment, is a dependently-originating element because it depends for its arising on what has gone before it. That is the meaning of Dependent Origination (paticcasamuppāda). ${ }^{37}$

\footnotetext{
${ }^{33}$ Vinaya Pitaka, I.14; S.III.66.

${ }^{34}$ Dhammapada, XX.279.

35 W. Rahula, What the Buddha Taught
} (Bangkok: Kurusapha Press, 1990), p. 58; Cf. Majjhima Nikāya, I. 228; Samyutta Nikāya, III. 132-133.

${ }^{36}$ Majjhima Nikāya, I.380.

${ }^{37}$ The law of Dependent Origination (paticcasamuppāda) applied to things in general and to man in particular is meant to suggest that things are arising dependent of something else,
Accordingly, the idea of an abiding, immortal substance in man or outside whether it is called "Self," "Soul" or "Ego," is considered only a false belief or a wrong view.

In contradistinction to the Suttanta Pitaka, the Bhagavadgitā declares that behind human body, senses, mind and intellect, which are subject to change and destruction, there is one undying principle, the Self. The Self is independent of the body and, on the dissolution of the body, it is not annihilated. ${ }^{38}$ However, we do not find any room for such speculative metaphysics in the Suttanta Pitaka. According to the Buddha, whatever is subject to change and suffering can not be the Self. The transcendental Self does not exist because it cannot be found either inside or outside the five aggregates (pañca-khandha), and the five aggregates are non-Self because they are found to be impermanent. Thus, while the Bhagavadgitā emphasizes that the Self is the inner controller of mind and body, ${ }^{39}$ the Suttanta Pitaka disagrees with this, denying such a controller of the five aggregates or mentality (nāma) and corporeality ( $r \bar{u} p a){ }^{40}$ This is

but not that one thing produces another thing in the strict sense of causality. In other words, things in the world are inter-dependent in some way or other. As it is said, "(1) When this is, that is (or when $A$ is, B is); (2) This arising, that arises (or $A$ arising, $B$ arises); (3) When this is not, that is not (or When $A$ is not, $B$ is not); (4) This ceasing, that ceases (or $A$ ceasing, $B$ ceases)." Majjhima Nikāya, II. 32. ${ }^{38}$ Bhagavadgitāa, II. 18 .

${ }^{39}$ Bhagavadgittā, III.42.

40 Majjhima Nikāya, I.232-233; Samyutta Nikāya, III.88, 188. 
the clear and fundamental difference between the Suttanta Pitaka and the Bhagavadgitā with regard to the Self.

\section{Action or Karma}

Concerning the concept of action (karma), both the Bhagavadgitā and the Suttanta Pitaka agree that all actions, whether good or bad, produce their proper consequences in the life of the individual who acts, provided they are performed with a desire for the fruits thereof. A person becomes good by performing good actions and bad by bad actions. He or she is liable to be born again and again until the effects of his or her previous actions have been exhausted and the seeds of fresh actions have ceased to be sown.

The Bhagavadgita believes that the law of action is under the guidance and control of God who creates the world in accordance with the law. It introduces God who promises to free his devotees from all sins, secure all attainment and safety to them and take even the person of most vile conduct to the highest goal. ${ }^{41}$

${ }^{41}$ Bhagavadgītā, XVIII.66; IX.22, 30, 32.
The Suttanta Pitaka, however, holds that the law of action (kamma) is autonomous and works independently of the will of God. The origin and order of the world, therefore, may be explained by the law of action without the supposition of God. ${ }^{42}$

According to the Bhagavadgitā, no one can remain without action, even for a moment. For all are made to action under compulsion by the qualities or modes (gunas) ${ }^{43}$ born of nature (prakrti). ${ }^{44}$ When action is undertaken with a desire for reward, it results in the accumulation of merit and demerit and leads to future births. But if a person acts without the desire for the result of action, he or she does nothing, even when continuously engaged in action, ${ }^{45}$ that person becomes free from the bondage of rebirth and attains the sorrowless state. This is called "skill in actions." 46

42 S.C. Chatterjee and D.M. Datta, An Introduction to Indian Philosophy (Calcutta: University of Calcutta, 1984), p. 16.

${ }^{43}$.The word "gunas" means qualities of modes inhering in nature (prakrti). The qualities or modes (gunas) are three, as follows: (1) Sattvas, the quality of illumination, which works towards purity, goodness, and happiness (2) Rajas, the quality of motion, which is the source of all activity (3) Tamas, the quality of inertia, which produces inactivity, sloth and sleepiness.

${ }^{44}$ Bhagavadgītā, III.5.

${ }^{45}$ Bhagavadgitā, IV.20, 21.

${ }^{46}$ Bhagavadgittā, II.50. 
In the Suttanta Pitaka, intentional action $(\text { kamma })^{47}$ is the sole controlling factor in the present existence of man and there is no supernatural interference whatsoever. ${ }^{48}$ When action (kamma) produces result, it is consciousness (viñกnana) ${ }^{49}$ that experiences it. But, consciousness (viñ̄nāna) which performs action is not identical with consciousness which experiences the result. Because, consciousness (viñ̄nana $)^{50}$ is interdependently in a flux of

47 The word "kamma" in the Suttanta Pitaka, means "intentional action" or "volitional action" only, not all action. (Anguttara Nikāya, III.415.) Intention (cetana $\overrightarrow{\text { ) }}$ is a specific definition for action. Action without intention is a mere happening, since it has not been intended, the action is as if it were not done. It will bear no result (vipāka), for it is not accumulated or stored up (upacita). However, action of the Buddha and Arahants who perform intentional action, is called "kiriy $\vec{a}$ " or "doing." Their action does not produce any effect, because they have eradicated greed (lobha) or passion (rāga), hatred (dosa) and delusion (moha) which are regarded as the roots of kamma. Accordingly, "doing" (kiriyā) which is not rooted in greed or passion, hatred and delusion does not produce result, too.

${ }^{48}$ Suttanipāta, 120.

49 The terms "citta" (consciousness) and " $m a n a "$ (mind) are said to be the synonyms for the consciousness (viñกnāạa).

${ }^{50}$ The significance in this connection is that even the consciousness (viñnana) is included, which is the innermost mental faculty and always regarded as a Self or Soul -a permanent entity that "feels, that experiences now here, now there the result of good or bad deeds." (Majjhima Nikāya, I. 258) As this arose in mind of a monk named Sati, the Buddha definitely declares, "Apart from condition there is no origination of consciousness" momentary change within the law of cause and effect, and there is nothing permanent, everlasting, unchanging and eternal in the world of existence. However, the volition (cetana), either good or bad, is accumulated by this consciousness (viñก̄ana), which in turn becomes the inducement to the present activity and originates the psycho-physical personality.

For the root cause of action (karma), the Bhagavadgitā regards ignorance (avidyā) and desire as the cause of deluded actions which are responsible for the continued chain of existence. ${ }^{51}$ It divides actions into two categories, namely; actions done with the desire which are called "sakāma karma," and actions done without a desire which are called "niskāma-karma." Here, the Bhagavadgītā disapproves of all actions performed with a desire for the results thereof. Since one cannot remain without the performance of karma or action even for a moment, ${ }^{52}$ the Bhagavadgitā instructs that one should control one's desires and perform actions in a disinterested manner as one's duty. ${ }^{53}$

(Majjhima Nikāya, I.257) Consciousness (viññ ana) comes into being (sambhoti) on account of duality, viz., the eye and the visible objects, which are impermanent, changing and becoming - other. The eye-consciousness (cakkhu-viñ̃āna) which arises through this changing duality, therefore, cannot be otherwise than changing. The same is applied to the other sense-organs and the consciousness (viñก̃āna) is named after them. (Samyutta Nikāya, IV. 67-69).

${ }^{51}$ Bhagavadgītā, VII.27.

${ }^{52}$ Bhagavadgìtā, III.8.

${ }^{53}$ Bhagavadgitā, IIII.19. 
When one performs actions in a disinterested manner, thinking oneself to be a mere instrument of God, one is not defiled by $\sin$ (pāpa). ${ }^{54}$ The Suttanta Pitaka also regards ignorance (avijjä) and desire as the causes of deluded actions which are responsible for the continued chain of existence. In this respect, the Buddha speaks of beings being reborn for an inconceivable length of time owing to the veil of ignorance and the fetter of craving. ${ }^{55}$ Both texts similarly view ignorance (avidy $\bar{a}$ or avijjâ) as causing craving or desire, which leads to clinging and the consequent chain of rebirth.

\section{Rebirth}

The Bhagavadgitā and the Suttanta Pitaka agree that beings are born again and again in different spheres of life driven by their karma-forces. As long as these karmaforces operate the chain of rebirth continues. The physical death, therefore, does not imply a gap or break in the perpetual flux of life. According to the Bhagavadgita the changes in the body do not mean changes in the Self. ${ }^{56}$ The human Self is a portion of God. It is neither born nor destroyed. When its body is worn out, the Self discards it and assumes a fresh body. It undergoes transmigration from one body to another. This transmigration is due to action. ${ }^{57}$ This static concept of a permanent and changeless Self in man is rejected outright

\footnotetext{
${ }^{54}$ Bhagavadgītā, V.10.

${ }^{55}$ Samyutta Nikāya, II. 178-180.

56 S. Radhakrishnan, The Bhagavadgittā, p. 104.

${ }^{57}$ Bhagavadgītā, III. 9.
}

by the Buddha. The process of rebirth finds a different explanation in Buddhism in the light of its dynamic concept of the world-process. It upholds the doctrine of rebirth without the concept of a Selfidentical substance or Soul. ${ }^{58}$ This is the principle of action and reaction, or cause and effect. This karma-force is technically called "bhavangasota" (subconsciousness-stream). There is no unchanged entity transmigrating from one life-process to another, but there is merely the process of continual change from moment to moment, from life to life, yet belonging to the same current of causeeffect continuum.

Hereby, different concepts of rebirth are clearly shown in the Bhagavadgita and the Suttanta Pitaka. The latter abandons the traditional concept of a permanent Self, dissolves static entities into dynamic processes and gives an empirical account of the processes of rebirth in place of a mysterious metaphysical explanation offered by the Bhagavadgitā. But in other respects, both texts are in agreement on the assertion of the validity of rebirth on the basis of paranormal experience. They also hold in common that karma or action is responsible for the event of rebirth, which in turn is due to ignorance and desire.

The Bhagavadgītā and the Suttanta Pitaka agree that life is full of suffering. There is life-suffering because there is birth (jāti). If a person were not born, he or she would

${ }^{58}$ K.N. Jayatilleke, Survival and Karma in Buddhist Perspective (Delhi: Motilal Banarsidass, 1983), p.32. 
not have been subject to the miserable state. Therefore, to stop rebirth is the basis of the cessation of suffering. In this connection, the Bhagavadgītā propounds its main thesis of desireless or disinterested action (niskāma-karma) through which right knowledge and consequent salvation are said to be attained. ${ }^{59}$ A person who has obtained this release goes to the perfect state. It consists of constant and eternal dwelling in Brahman and in permanent release from the process of transmigration. The Suttanta Pitaka also declares that in order to stop rebirth it is necessary to stop kamma by eradicating desires and attachments. One must get rid of ignorance by the true knowledge or knowledge of the Four Noble Truths. ${ }^{60}$ Through the utter cessation of ignorance, all actions and their fields are also extinguished. Such a person is free, liberated from the constant cycle of rebirth.

\section{Salvation (Enlightenment or Nirvāṇa)}

With regard to the concept of salvation (nirvāṇa or nibbāna), the Buddha declares Nibbāna to be the highest of all things. He frequently says: "Nibbāna is the supreme happiness. ${ }^{161}$ This indicates that through the attainment of Nibbāna all sorts. of suffering come to an end completely, and there is no scope for their further revival. There is only happiness; nothing else after

\footnotetext{
${ }^{59}$ Bhagavadgītā, IV.38.

${ }^{60}$ Dhammapada, XIV.190-191.

${ }^{61}$ Majjhima Nikāya, I.508; Dhammapada, XV. 203, 204.
}

that. ${ }^{62}$ Nibbāna is the supreme happiness, because it is not a kind of happiness that is experienced by the senses. It can be directly and personally realized by the wise. $^{63}$ Once it is attained, there is no falling down again. ${ }^{64}$

On the other hand, the Bhagavadgitā brings the term "nirvāṇa" metaphysical and theological elements and lays more emphasis on positive rather than on negative description, such as "the supreme peace," "the highest goal," "the eternal abode," "the supreme perfection $^{165}$ and so on. Definitely, the positive realization of the Atman or Brahman is the dominant note of view of salvation in the Bhagavadgita. Naturally, the Bhagavadgitā, like the Suttanta Pitaka which speaks of Nibbāna as the destruction of desire or craving, ${ }^{66}$ declares that the attainment of Nirvāna can be achieved by abandoning all desires. ${ }^{67}$ However, the Bhagavadgitā repeats the exhortation for giving up desire and egoism, ${ }^{68}$ and persists in clinging to the Self, so much so that salvation is regarded by it as the state of Self-absorption. ${ }^{69}$ Thus, Nirvāna according to the Bhagavadgitā is said to consist of the identification or unification with the metaphysical reality called "âtman" or

\footnotetext{
${ }^{62}$ Visuddhimagga I., p. 260.

${ }^{63}$ Majjhima Nikāya, I.37.

${ }^{64}$ Suttanipāta, 50.

65 Bhagavadgītā, V.21; VI.21; XIV.27; IV.39; XVIII.62; VI.45; VIII.13; XVIII.49; XVIII.56, 62.

${ }^{66}$ Samyutta Nikāya, I.39- 40.

${ }^{67}$ Bhagavadgìtā, II.71.

${ }^{68}$ Bhagavadgìtā, III.27; XVIII.17.

${ }^{69}$ Bhagavadgīiāā, II.55.
} 
"brahman," whereas salvation (nibbāna) in the Suttanta Pitaka does not consist of any metaphysical Self or God. It is only the state free from desires, ${ }^{71}$ which only the wise can realize directly and personally. ${ }^{72}$ Considering the similarity of views of salvation in the Bhagavadgita and the Suttanta Pitaka, there appears to be a general agreement between the two texts with regard to their description of Nirvāna or nibbāna (through negative and positive definitions) as well as their references to the inexpressibility or incomprehensibility of this supreme state. The approach to nibbāna of the Suttanta Pitaka is predominantly negative whereas that of the Bhagavadgita is largely positive.

Regarding the way to salvation, the Bhagavadgītā first renders that all aspirants can reach the goal of perfection and attain the saving truth or salvation in three different ways; by a knowledge of reality (jñānayoga), by devotion (bhaktiyoga) and by action without concern for the fruit (karmayoga). ${ }^{73}$ These are distinguished on account of distribution of emphasis on the theoretical, emotional and practical aspects. But they are in essence the same, not different. Devotion (bhakti) and knowledge (jñāna) are described as only two different approaches to the same reality, conceived

70 Bhagavadgītā, V.19, 20, 24; XI.54; XVIII.55.

71 yo kho avuso ragakkhayo dosakkhayo mohakkhayo, idam vuccati nibbānan ti, Samyutta Nikāya, IV.251, 261.

${ }^{72}$ Majjhima Nikāya, I.37.

${ }^{73}$ S. Radhakrishnan, The Bhagavadgittā, p. 53. by turn as personal and impersonal. Likewise, the ways of knowledge (jīana) and action (karma) also are said to be essentially one, since the same spirit of renunciation constitutes the kernel of both. The Bhagavadgita itself seeks to establish the same doctrine of renunciation in action. The desireless or disinterested action (niskāma-karma) is made the central point in which all the paths are shown to converge. Thus, knowledge, devotion and action merge together at the end.

According to the Suttanta Pitaka, the way leading to salvation is the Middle Way (majjhimāpatipadā). Avoiding the two extremes of self-indulgence ( $k a \bar{m} m a s u k h a l-$ likānuyoga) and self-mortification (attakila-mathānuyoga), the Buddha taught his followers to take the Middle Way. ${ }^{74}$ It is generally referred to as the Noble Eightfold Path, ${ }^{75}$ because it is composed of eight categories, namely, Right Understanding, Right Thought, Right Speech, Right Action, Right Livelihood, Right Effort, Right Mindfulness and Right Concentration. The mentioned factors must be followed in a successive manner. Right understanding (sammāditthi) is essentially treated as the progressive factor of the other paths, because if the view is right, the remaining paths would automatically be right respectively. The Noble Eightfold Path may be adjusted in the Threefold Training (tisikkhā), namely,

74 Samyutta Nikāya, V.420; Vinaya Pitaka, I. 10 .

${ }^{75}$ Samyutta Nikāya, V.421; Digha Nikāya, II. 321; Majjhima Nikāya, I.61; Vinaya Pitaka, I. 10 . 
training in higher morality, training in higher concentration and training in higher wisdom. ${ }^{76}$ Practically, morality (sila), concentration (samādhi), wisdom (pañ̄â) and deliverance (vimutti) or salvation (nibbāna) are causally conditioned and represent the progressive stages of the holy path. One is first said to cultivate morality, ${ }^{77}$ then enter into concentration, ${ }^{78}$ through which the practitioner acquires knowledge and insight, ${ }^{79}$ and having attained perfect knowledge, he or she is finally released. ${ }^{80}$

Likewise, the idea that virtue, wisdom and salvation are inter-linked, is also well expressed in the Bhagavadgītā. The need for self-control and moral discipline is emphasized for securing the state of concentration whereby knowledge and consequent salvation are said to be attained. It is said: "The person of faith endeavoring with the control of senses (samyatendriyah) attains wisdom (labhate jn̄anam) and having attained wisdom, he or she in no time achieves supreme peace (nirvāna)." ${ }^{11}$ Through the practical way leading to salvation, therefore, the Bhagavadgita is found to be in general agreement with the Suttanta Pitaka.

According to the Suttanta Pitaka, there are two kinds of salvation, namely, salvation with the substratum of life remaining

76 Digha Nikāya, III.219-229; Anguttara Nikāya, I.229; Itivuttaka, 51.

${ }^{77}$ Majjhima Nikāya, I.200.

${ }^{78}$ Majjhima Nikāya, I.201.

${ }^{79}$ Majjhima Nikāya, I.202.

${ }^{80}$ Majjhima Nikāya, III.76.

${ }^{81}$ Bhagavadgītā, IV.39. (saupādisesanibbāna) and salvation without any substratum of life remaining (anupādisesa-nibbāna). The former refers to Nibbāna of the disciple who attains the state of Arahantship and is still alive. The latter is the Nibbāna of the disciple who had attained the state of Arahantship and has passed away at the end of his life. ${ }^{82}$

In the Bhagavadgitā, the word "nirvāna" is also clearly used as it is experienced before and after death. ${ }^{83}$ Nirvāna which is experienced by the liberated saint so long as he lives, is called "brāhmīsthiti," meaning the state of jivanmukta, i.e. released while still living, and Nirvāna at the end of his life span is called "brahmanirvāṇa," i.e. absorption in Brahman after death. ${ }^{84}$ Thereupon, both the Bhagavadgitā and the Suttanta Pitaka are in agreement that salvation which is the ultimate goal of the holy life can be attained here on earth in this very life and after death or after the expiry of life.

Considering the attainment of salvation as the ultimate goal of the holy life, both the Bhagavadgitā and the Suttanta Pitaka hold that their ethical teachings are derived from this supreme consideration. All forms of conduct which promote the release of man from the worldly suffering and tend to attain the highest goal are righteous and their opposites are unrighteous actions. According to the Suttanta Pitaka, what one thinks or wills, is of primary or direct ethical value,

82 Itivuttaka, 38.

83 Bhagavadgìtā, II.72.

84 Bhagavadgìtā, II.72; Cf. M.R. Yardi, The Bhagavadgitä As a Synthesis, p. 325. 
whereas what one outwardly speaks or acts has a secondary or indirect ethical significance. The inner will or volition (cetan $\vec{a})$ is regarded as the prime spring of moral action. ${ }^{85}$ Therefore, the inner purity or impurity of the mind is the root of all righteous or unrighteous actions respectively.

\section{Ethics $^{86}$}

In the Bhagavadgitā, the most fundamental standard of morality is also derived from the supreme consideration of the highest goal (nirvāna), though in view of its teaching of the tripartite path to salvation, it differs in certain respects from the Suttanta Pitaka. But even so, it shows that attachment (rāga), hatred (dvesa) and delusion (moha) are regarded as the basic roots of all unrighteous actions. By abandoning these, one's actions are said to become free from all defilements, and one is said to realize the supreme serenity. ${ }^{87}$ People are also instructed to be absorbed in rendering good to all beings and remain free from enmity or ill-will. ${ }^{88}$ However, the Bhagavadgitā seems to lay an almost exclusive emphasis on the control of the inner will or desire so much so that all actions are said to become ethically insignificant, if one gets perfect

\footnotetext{
${ }^{85}$ Dhammapada, I.1-2.

${ }^{86}$ Ethics is the moral philosophy which investigates the problems of morality such as the standard of moral judgement, the problem of righteous and unrighteous actions and their cognate problems. Here, the ethical codes of conduct and behavior will be examined.

${ }^{87}$ Bhagavadgītā, II.52, 64 .

${ }^{88}$ Bhagavadgītā, XI.55; XII.13.
}

control over one's desire. ${ }^{89}$ It is under this plea that the Bhagavadgitā sanctions even somewhat morally defective actions (sadosamapi) ${ }^{90}$ and justifies them in the name of the duty for duty's sake. In this case, the sin of a devotee of God may be condoned, if he or she performs the actions in dedication to God. ${ }^{91}$

Both the Bhagavadgitā and the Suttanta Pitaka hold that morality is the initial requirement of the holy life which prepares the ground for the development of higher faculties. By this means, true knowledge is attained and salvation realized. It is not an end in itself, but only a means leading to the state of inner purification and concentration whereby the supreme end or ultimate goal of life is attained. In the Bhagavadgit ā, there are two kinds of human nature; the divine (daivissampat) and the demoniac (asurasampat) or the good and the bad. The divine nature is the moral endowment which helps man to lead a life that is in harmony with the will of God, while the demoniac nature is a fund of inherited qualities which leads man into wrong doing. ${ }^{92}$ Actually, wrong doing is rooted in desire or lust ( $k \bar{a} m a)$, anger (krodha) and greed (lobha); a threefold gate of hell. Therefore, a person who is released, does what is good for the soul and then reaches the highest state (nirvāṇa). ${ }^{93}$

\footnotetext{
${ }^{89}$ Bhagavadgītā, IV.20.

${ }^{90}$ Bhagavadgītā, XVIII.48.

${ }^{91}$ Bhagavadgìtā, 10; XVIII.56-58.

${ }_{22}$ M. Rangacharya, The Hindu Philosophy of Conduct: Lectures on the Bhagavadgitāa (Delhi: Munshiram Manoharlal Publishers, 1990), p. 150.

${ }^{93}$ Bhagavadgītā, XVI.22.
} 
With regard to the problem of morality, some practical ways and means which are suggested by the Bhagavadgitā and the Suttanta Pitaka are very similar, however, they also have some differing aspects in their views of morality.

According to the Suttanta Pitaka, the perfect saint, having attained the state of absolute desirelessness or perfect freedom from passion (rāga), hatred ( delusion (moha), is said to be incapable of doing morally wrong actions or committing any evil deed. However, according to the Bhagavadgitta, one who has shaken off desire or attachment in all its forms may, in the face of certain exigencies, perform wrong action and yet remain uncontaminated by $\sin .{ }^{94}$ In the Suttanta Pitaka, wrong actions are irrevocably associated with evil consequences, of which there is no exception. Thus, performance of wrong action is a sure sign of imperfection in holiness. In the Bhagavadgita, there is a definite exception made in the case of an absolutely unconceited and detached person who kills but is not bound by his or her action. ${ }^{95}$ It is prescribed by the Bhagavadgitā that those who are detachedly engaged in the relentless discharge of their divinely-ordained social duty (svadharma), can attain perfection, despite inherent defects in their . profession. ${ }^{96}$

Accordingly, people are required to perform their own duty relentlessly and

\footnotetext{
${ }^{94}$ Bhagavadgītā, II.38; IV.21; V.10.

${ }^{95}$ Bhagavadgītā, XVIII.17.

${ }^{96}$ Bhagavadgītā, XVIII.45, 47.
}

dispassionately, irrespective of the consequences, for each person is to attain perfection by discharging his or her own duty with a detached view. ${ }^{97}$ To fight gallantly in the battle and not to run away from it is one of the prescribed duties of a king (ksatriya). As a king, Arjuna was persuaded on moral grounds that his fighting against an evil-doer involves no $\sin ^{98}$ On the contrary, if he does not fight in the righteous battle, he will fail in his duty and incur $\sin .{ }^{99}$ Therefore, it is no wonder that the battle or fighting against evil-doers is called by the Bhagavadgitā a righteous battle (dharmyam saṃgrāmam). ${ }^{100}$

Being different from the Bhagavadgitā, the Suttanta Pitaka rejects the concepts of divinely ordained or prescribed natural duties (svadharma), and points out that the Buddha teaches the noble doctrine as the only duty of each person. ${ }^{101}$ According to the Buddha, it is not possible for a detached and enlightened person to commit sins. Generally, the teaching of the Buddha is to overcome anger with love and not with anger; evil with good and not with evil. ${ }^{102} \mathrm{~A}$ man who conquers in battle a thousand times a thousand men, is not the noblest victor, but he who conquers himself is, indeed, the greatest of conquerors. ${ }^{103}$ Therefore, this attitude of practical morality in the Suttanta Pitaka is

\footnotetext{
97 Bhagavadgītā, XVIII.49.

98 Bhagavadgītā, II.38; V.10.

99 Bhagavadgìtā, II.33.

${ }^{100}$ Bhagavadgītā, II.33.

${ }^{101}$ Majjhima Nikāya, II.181.

${ }^{102}$ Dhammapada, XVII.223.

${ }^{103}$ Dhammapada, VIII.103.
} 
quite different from that of the Bhagavadgītā.

\section{Conclusion}

In the light of what has been said above, it can be concluded that the approach of the Bhagavadgita is mainly metaphysical and it offers solutions mostly on the basis of traditional metaphysical presuppositions, whereas the approach of the Suttanta Pitaka is thoroughly empirical in which the traditional metaphysical speculations are brushed aside.

The Bhagavadgita maintains that the Self which is identical with God is the creator, the sustainer and the destroyer of the world. It is the highest goal of life. But the Suttanta Pitaka rejects the existence of God or the eternity of soul and maintains that Nibbāna or Nirvāna, which is the state free from passion (rāga), hatred $(d o s a)$ and delusion (moha), is the ultimate truth and the ultimate goal of the Buddhists. Concerning ignorance (avijjä), which is the cause of rebirth through the action committed by people, the Suttanta Pitaka says that ignorance should be removed through wisdom arising in one's own self, but the Bhagavadgitā encourages that one should remove ignorance through devotion (bhakti) to God.

Considering the ethical point of view, both texts agree that one will receive the result of one's own action which is done with intention and attachment. However, the Suttanta Pitaka emphasizes that the actions performed with intention to remove all kinds of defilement (kleśa) are good actions, whereas, the Bhagavadgitā lays emphasis on the fact that all actions performed in service of God are good actions.

Although, the Bhagavadgitā and the Suttanta Pitaka differ regarding the concept of God and Self, their direct aims are similar in offering direction and proper guidance of human conduct. Both texts suggest practical ways and means to solve the pressing problems of life and to attain the state of supreme perfection.

\section{References}

Anderson, D. and Smith, H. Ed. 1979. Suttanipāta. London: Pali Text Society, 1948.

Deussen, P. The Philosophy of the Upanisads. Delhi: Oriental Books.

Feer, M.L. Ed., Samyutta Nikāya (5 Vols.). London: Pali Text Society, 18841904.

Gambhirananda, Swami. 1991.

Bhagavadgītā With the

Commentary of Sanikarācārya.

Calcutta: Advaita Ashrama.

Jayatilleke, K.N. 1983. Survival and Karma in

Buddhist Perspective. Delhi: Motilal

Banarsidass.

Lay, U Ko. 1988. Guide to TipiTaka. Delhi: Sri Sutguru Publications. Mererk, Prayoon. Selflessness in Sartre's

- Existentialism and Early Buddhism. Bangkok: Mahachula Buddhist University.

Morris, R. and Hardy, E. Ed., Añguttara Nikāya

(5 Vols.). London: Pali Text

Society, 1885-1900.

Myanmar Pitaka Association. 1990. Twenty-

Five Suttas from Majjhima paṇāāa.

Delhi: Sri Sutguru Publications. 
The Metaphysics and Ethics According to the Bhagavadgītā and the Suttanta Pitaka

Myanmar Pitaka Association. 1990. Twenty-

Five Suttas from Mülapaṇāsa. Delhi: Sri Sutguru Publications.

Oldenberg, Hermann. Ed. 1879. Vinaya Pitaka Vol. I. London: Pali Text Society.

Radhakrishnan, S. 1993. Indian Philosophy, Vol. 1. Delhi: Oxford University Press. . 1994. The Bhagavadgitta.

Delhi: HarperCollins Publishers. 1994. The Principal

Upanisads. New Delhi:

HarperCollins Publishers.

Rahula, W. 1990. What the Buddha Taught.

Bangkok: Kurusapha Press.

Rangacharya, M. 1990. The Hindu Philosophy

of Conduct: Lectures on the

Bhagavadgitā. Delhi: Munshiram

Manoharlal Publishers.

Rhys Davids, C.A.F. Ed., Visuddhimagga (2 Vols). London: Pali Text Society, 1920-1921.

Rhys Davids, T.W. and Carpenter, J.E., Ed., Digha Nikāya (3 Vols). London: Pali Text Society, 1890-1911.
Sumangala Thera, S. Ed. 1914. The

Dhammapada. London: Pali Text Society.

Tapasyananda, Swami. 1994. Srimad Bhagavadgitā; The Scripture of Mankind. Madras: Sri Ramakrishna Math.

Thomas, E.J. 1993. The Life of Buddha As Legend and History. Delhi: Motilal Banarsidass Publishers.

Trenkner, V. Ed. 1928. Milindapañhā London: Pali Text Society.

Trenkner, V. and Chalmers, R. Ed., Majjhima Nikāya (3 Vols). London: Pali Text Society, 1948-1951.

Upadhyaya, K.N. 1983. Early Buddhism and the Bhagavadgitā. Delhi: Motilal Banarsidass.

Windisch, E. Ed. 1889.Itivuttaka. London: Pali T exts Society.

Yardi, M.R. 1991. The Bhagavadgìtā As a Synthesis. Poona: The Bhandarkar Institute Press. 